\title{
Audit of Antenatal Services in Primary Healthcare Centres in Jos, Nigeria.
}

\author{
Atiene S Sagay', Chinedu C Ekwempu', Musa Kabiru ${ }^{2}$, Patrick C Daru' and Aderemi O Aisien'. \\ Departments of Obstetrics \& Gynaecology, 'Jos University Teaching Hospital, Jos and ${ }^{3}$ University of Benin \\ Teaching Hospital, Ugbowo, Benin City; ${ }^{2}$ Nasarawa State Specialist Hospital, Lafia, Nassarawa State, Nigeria.
}

\begin{abstract}
Introduction: Maternal mortality remains a big challenge in developing countries including Nigeria where the figures are amongst the highest in the world. The Nigerian government's response in providing primary healthcare centres (PHCs) in all local government areas is commendable but access to quality antenatal care is still poor. The high proportion of maternal deaths resulting from late referrals from PHC's to the Jos University Teaching Hospital (JUTH), prompted this study to audit antenatal services in PHC's in Jos.

Methods: Six of the 12 PHC's in Jos were randomly sampled and 425 consecutive antenatal clinic attendees were recruited for the study. In each case, the client's records were scrutinized and a detailed history and physical examination was conducted. Details of personal data and of antenatal care provided were tabulated and analyzed using frequencies.

Results: The results showed that $35.5 \%$ of pregnant women receiving antenatal care at PHCs in the Jos area were clients with high-risk pregnancies. Over two-thirds of the pregnant women received antenatal care in the PHCs without blood pressure surveillance. Maternal weight was regularly checked in $78.1 \%(332 / 425)$ but height was not recorded in any woman. Sickling test/genotype and VDRL were not done and no client received malaria prophylaxis. Conclusion: The study showed that the standard of antenatal care offered in PHCs in Jos fell short of the required level and represents a missed opportunity to impact on the poor maternal and perinatal health statistics in the area.
\end{abstract}

Key Words: Antenatal care, Standard of care, Audit, Nigeria.

\section{Introduction}

The death of a mother is a great tragedy in any society. Whereas the maternal mortality ratios have stabilized at relatively low figures for many years in the industrialized nations, the figures remain high in the developing world. The life time risk of death as a result of pregnancy and child birth is estimated to be 1 in 23 in some African countries compared with 1 in 7000 in Northern Europe ${ }^{t}$.The situation in Nigeria is just as tragic with a maternal mortality ratio of about $735 / 100,000^{2}$. Most of the deaths are due to preventable causes such as haemorrhage, pregnancy induced hypertension and sepsis as opposed to what obtains in most developed nations where the maternal deaths are largely due to indirect causes ${ }^{3}$. Poor access to health care facilities and especially to antenatal care remains a problem in this environment where barely $60 \%$ of pregnant women have access to $\mathrm{ANC}^{4}$.

The Alma Ata declaration in 1978 adopted primary health care, as a global strategy for promoting health for all by the year 2000 , a policy that was adopted by Nigeria in 1988. The emphasis was on preventive rather than curative medicine. To improve access to affordable antenatal care for pregnant women, the federal ministry of health through the states and local governments established primary healthcare centres (PHCs) in all local government areas in this country. The aim was to achieve a substantial reduction in maternal and perinatal deaths. In spite of the establishment of these facilities, referrals from PHCs to tertiary institutions remain high with most of the cases in a bad state of health resulting in poor obstetric outcomes. The in the this study was the high proportion of avoidable maternal deaths occurring in the maternity unit of Jos University Teaching Hospital (JUTH) resulting from late referrals from PHCs around Jos. The objective of the study was to evaluate the quality of antenatal care services in PHCs around Jos.

\section{Materials and Methods}

Six of the 12 PHCs in Jos were randomly selected for the study using a random number table. Patients were recruited for the study as they presented to the antenatal clinics in the PHCs. A total of 425 patients were recruited for the study. Information was obtained regarding age, parity, education, previous postpartum haemorrhage, hypertension, previous caesarean section and unexplained fetal death. The data on height, weight and blood pressure were also obtained at booking and subsequent visit. The estimation of gestational age from LMP or fetal "quickening" or symphysio-fundal height measurement or by ultrasound were recorded. Detailed history of previous pregnancies, antenatal investigations (blood grouping, sickling test or genotype, VDRL, urinalysis) and information on antenatal drugs (folic acid, fersolate and anti-malarials) were obtained by reviewing the antenatal records.

The patients were examined for high blood pressure, previous caesarean section scars, fetal mal-presentation

Correspondence: Atiene S. Sagay, Jos University Teaching Hospital; PMB 2076, Jos, Nigeria.

E-mail: atsagay58@yahoo.com 
and multiple pregnancy. The aim was to identify highrisk pregnancies. A woman is considered high risk when she is found to have associated conditions that are likely to adversely affect pregnancy outcome.
The gestational ages of the pregnancies were calculated using the Naegele's rule and compared with the already calculate gestational age at booking by the midwives at the PHCs. The data was analyzed using simple percentages.

Table 1.

Parity distribution of pregnant women booked at PHCs in Jos, Nigeria.

\begin{tabular}{|c|c|c|c|c|c|c|c|}
\hline Parity & Stadium & Bukuru & Nasarawa & T/Wada & $\begin{array}{l}\text { Angwan } \\
\text { Rogo }\end{array}$ & $\begin{array}{l}\text { Abba } \\
\text { Nashehu }\end{array}$ & Total \\
\hline 0 & 19 & 24 & 26 & 15 & 8 & 9 & $\begin{array}{l}101 \\
(23.8 \%)\end{array}$ \\
\hline $1-4$ & 43 & 60 & 58 & 29 & 28 & 30 & $\begin{array}{l}248 \\
(58.3 \%)\end{array}$ \\
\hline 5 and over & 13 & 16 & 16 & 6 & 14 & 11 & $\begin{array}{l}76 \\
(18.1 \%)\end{array}$ \\
\hline Total & 75 & 100 & 100 & 50 & 50 & 50 & 425 \\
\hline
\end{tabular}

Table 2:

Distribution by formal education

\begin{tabular}{|c|c|c|c|c|c|c|c|}
\hline $\begin{array}{l}\text { Educational } \\
\text { Status }\end{array}$ & Stadium & Bukuru & Nasarawa & T/Wada & $\begin{array}{l}\text { Angwan } \\
\text { Rogo }\end{array}$ & $\begin{array}{l}\text { Abba } \\
\text { Nashehu }\end{array}$ & $\begin{array}{r}\text { Total } \\
(\%)\end{array}$ \\
\hline Illiterate & 26 & 22 & 40 & 16 & 24 & 25 & $153(36.0)$ \\
\hline Primary & 25 & 39 & 42 & 22 & 18 & 15 & $161(37.9)$ \\
\hline Secondary & 22 & 39 & 16 & 10 & 6 & 9 & $102(24.0)$ \\
\hline Tertiary & 12 & - & 2 & 2 & 2 & 1 & $\begin{array}{r}9(2.1) \\
425(100)\end{array}$ \\
\hline
\end{tabular}

\section{Results}

Table 1 showed that $178(41.9 \%)$ of the antenatal patients were primigravida or grand-multiparous. Table 2 showed that $314(74 \%)$ of the patients were either illiterate or had only primary education and only $9(2 \%)$ had post secondary education. The majority of patients $(55.5 \%)$ were aged 20 to 29 years (Table 3 ).

The weights of $332(78.1 \%)$ patients were checked at booking while $132(31.1 \%)$ women had their blood pressures measured at each visit. Only one $(0.2 \%)$ patient had a general physical examination done and recorded at booking. The last menstral period was used to date pregnancies in $234(57.1 \%)$ of the cases, but when the derived expected dates of delivery cross checked, only in $151(36.0 \%)$ patients, had the Naegele's rule been correctly applied. None of the patients had their pregnancies dated by ultrasound. Height measurement was not done for any of the patients. A detailed history of previous pregnancies was obtained in $15(3.5 \%)$ of the cases. Haemoglobin levels were checked in 275 patients and the blood group in $247(58.1 \%)$ patients. Sickling test, genotype and VDRL were not done for any of the patients. Urinalysis for sugar and protein was done in $77.6 \%$ of patients. Iron and folic acid was administered to $413(97.2 \%)$, but no patient received malaria prophylaxis.

\section{Discussion}

Two major findings came to light is this study. Firstly, about one-third of pregnant women receiving antenatal care at PHCs in the Jos area are clients with high-risk pregnancies. Secondly, the standard of antenatal care at the PHC's studied falls short of the required level and represents a missed opportunity to impact on the poor maternal and perinatal health statistics in the area.

The educational profile of antenatal clients in this study, indicate that PHC attendees are principally from the lower social classes in the community. Women of higher educational status tend to go to secondary and tertiary health facilities where they believe better facilities and manpower exist. This finding is consistent with other studies. ${ }^{4}$ We observed that $41.9 \%$ of the attendees were primigravid and grand multiparous patients considered to be high risk, requiring specialist care..$^{6-8}$ Other highrisk conditions managed in these centres include, hypertension in pregnancy $(2.8 \%)$, previous Caesarean section $(1.4 \%)$, antepartum haemorrhage in the index 
Table 3:

Examination done at antenatal booking and subsequent visits

\begin{tabular}{|c|c|c|c|c|c|c|c|}
\hline & Stadium & Bukuru & Nasarawa & T/Wada & $\begin{array}{c}\text { Angwan } \\
\text { Rogo }\end{array}$ & $\begin{array}{l}\text { Abba } \\
\text { Nashehu }\end{array}$ & Total $(\%)$ \\
\hline $\begin{array}{l}\text { Height at } \\
\text { Booking }\end{array}$ & - & - & - & - & - & - & $0(0.0 \%)$ \\
\hline $\begin{array}{l}\text { Weight } \\
\text { Checked at } \\
\text { Every visit. }\end{array}$ & $\begin{array}{c}70 \\
(93.3 \%) \\
:\end{array}$ & $\begin{array}{c}95 \\
(95 \%)\end{array}$ & $\begin{array}{c}34 \\
(34 \%)\end{array}$ & $\begin{array}{c}40 \\
(80 \%)\end{array}$ & $\begin{array}{l}50 \\
(100 \%)\end{array}$ & $\begin{array}{c}43 \\
(86 \%)\end{array}$ & $\begin{array}{c}332 \\
(78.1 \%)\end{array}$ \\
\hline $\begin{array}{l}\text { Physical } \\
\text { Examination } \\
\text { Done and } \\
\text { Recorded }\end{array}$ & - & - & - & - & $\begin{array}{c}1 \\
(2 \%)\end{array}$ & - & $\begin{array}{c}1 \\
(0.025)\end{array}$ \\
\hline $\begin{array}{l}\text { Blood } \\
\text { Pressure } \\
\text { Measured at } \\
\text { Each visit }\end{array}$ & $\begin{array}{c}69 \\
(92 \%)\end{array}$ & $\begin{array}{c}7 \\
(75 \%)\end{array}$ & $\begin{array}{c}20 \\
(20 \%)\end{array}$ & $\begin{array}{c}20 \\
(40 \%)\end{array}$ & $\begin{array}{c}14 \\
(28 \%)\end{array}$ & $\begin{array}{c}2 \\
(4 \%)\end{array}$ & $\begin{array}{c}132 \\
(31.1 \%)\end{array}$ \\
\hline $\begin{array}{l}\text { Subjective } \\
\text { Dating of } \\
\text { Pregnancy }\end{array}$ & $\begin{array}{c}60 \\
(80 \%)\end{array}$ & $\begin{array}{c}57 \\
(57 \%)\end{array}$ & $\begin{array}{l}80 \\
(80 \%)\end{array}$ & $\begin{array}{c}15 \\
(30 \%)\end{array}$ & $\begin{array}{c}20 \\
(40 \%)\end{array}$ & $\begin{array}{c}11 \\
(22 \%)\end{array}$ & $\begin{array}{c}234 \\
(57.1 \%)\end{array}$ \\
\hline $\begin{array}{l}\text { Dating by } \\
\text { USS* }\end{array}$ & - & - & - & - & - & - & $\begin{array}{c}0 \\
(0.0 \%)\end{array}$ \\
\hline $\begin{array}{l}\text { History of } \\
\text { Prev. Preg. }\end{array}$ & - & $\begin{array}{c}3 \\
(3 \%)\end{array}$ & - & $\begin{array}{c}10 \\
(20 \%)\end{array}$ & $\begin{array}{c}2 \\
(4 \%)\end{array}$ & - & $\begin{array}{c}15 \\
(3.5 \%)\end{array}$ \\
\hline
\end{tabular}

* Ultrasound scan

Table 4:

Calculation of gestational Age by Naegele's Rule

\begin{tabular}{lccccccc}
\hline $\begin{array}{l}\text { Gestational } \\
\text { Age }\end{array}$ & Stadium & Bukuru & Nasarawa & T/Wada & $\begin{array}{c}\text { Angwan } \\
\text { Rogo }\end{array}$ & $\begin{array}{c}\text { Abba } \\
\text { Nashehu }\end{array}$ & Total \\
\hline $\begin{array}{l}\text { Correctly } \\
\text { calculated }\end{array}$ & 32 & 33 & 41 & 20 & 17 & 8 & 151 \\
Wrongly & 18 & $(43 \%)$ & $(41 \%)$ & $(40 \%)$ & $(34 \%)$ & $(16 \%)$ & $(36 \%)$ \\
calculated & $(24 \%)$ & $(40 \%)$ & $(7 \%)$ & $(14 \%)$ & $(10 \%)$ & $(12 \%)$ & $(19.5 \%)$ \\
$\begin{array}{l}\text { Not } \\
\text { calculated }\end{array}$ & 3 & 6 & 3 & 4 & 2 & 1 & 19 \\
$\begin{array}{l}\text { Uncertain } \\
\text { of date }\end{array}$ & $(4 \%)$ & $(6 \%)$ & $(3 \%)$ & $(8 \%)$ & $(4 \%)$ & $(2 \%)$ & $(4.5 \%)$ \\
\hline
\end{tabular}

pregnancy $(1.2 \%)$, drainage of liquor $(3.3 \%)$, previous post-partum haemorrage $(10.3 \%)$, malpresentation at term $(4.7 \%)$ and previous unexplained fetal deaths $(7.8 \%)$. Previous obstetric history was not documented in $410(96.5 \%)$ of the antenatal records scrutinized. None of the records showed the heights of clients and full physical examination was entered in only one $(0.2 \%)$ case. Clearly, these deficiencies in the antenatal evaluation of patients in these centres hampered the detection of high-risk cases.

The healthcare providers in the PHCs were largely of modest clinical abilities, given that in $35.5 \%$ ( 83 of 234) of cases, the EDD on the antenatal card had been incorrectly computed from the last menstrual period. In all, about two-thirds of the clients reviewed did not have a proper subjective dating of pregnancy. The contribution of accurate determination of gestational age to neonatal and maternal outcome is well known ${ }^{9,10}$ It has been shown that an ultrasound scan done in pregnancy, especially before 20 weeks is of value in reducing mortality and morbidity resulting from wrong dates, multiple pregnancies and fetal malformations. ${ }^{9,11}$ However, despite the availability of ultrasound services in numerous centres in Jos metropolis, none of the cases 
Table 5:

High-risk antenatal cases booked at PHC's in Jos

\begin{tabular}{|c|c|c|c|c|c|c|c|}
\hline & Stadium & Bukuru & Nasarawa & T/Wada & $\begin{array}{l}\text { Angwan } \\
\text { Rogo }\end{array}$ & $\begin{array}{l}\text { Abba } \\
\text { Nashehu }\end{array}$ & Total \\
\hline Hypertension & - & 2 & 3 & 3 & 2 & 1 & $12(2.8 \%)$ \\
\hline $\begin{array}{l}\text { Unexplained } \\
\text { Fetal death }\end{array}$ & 10 & 8 & 7 & 1 & 5 & 2 & $33(7.8 \%)$ \\
\hline $\begin{array}{l}\text { Previous } \\
\mathrm{C} / \mathrm{S}\end{array}$ & 2 & 2 & 1 & 1 & - & - & $6(1.4 \%)$ \\
\hline $\begin{array}{l}\text { Threatened } \\
\text { Abortion in } \\
\text { Index } \\
\text { Pregnancy }\end{array}$ & 3 & 2 & 8 & 2 & 2 & 1 & $17(4.0 \%)$ \\
\hline $\begin{array}{l}\text { APH in index } \\
\text { Pregnancy }\end{array}$ & 1 & 1 & 2 & 1 & - & - & $5(1.2 \%)$ \\
\hline $\begin{array}{l}\text { Malpresentation } \\
\text { At term }\end{array}$ & 4 & 6 & 4 & 4 & 1 & 1 & $20(4.7 \%)$ \\
\hline $\begin{array}{l}\text { Drainage of } \\
\text { Liquor }\end{array}$ & 1 & 1 & 6 & 3 & 3 & - & $14(3.3 \%)$ \\
\hline $\begin{array}{l}\text { PPH in previous } \\
\text { Deliveries }\end{array}$ & 9 & 8 & 10 & 7 & 4 & 6 & $44(10.3 \%)$ \\
\hline $\begin{array}{l}\text { Proportion of } \\
\text { Patients with } \\
\text { High risk }\end{array}$ & $\begin{array}{c}29 \\
(35 \%)\end{array}$ & $\begin{array}{c}30 \\
(30 \%)\end{array}$ & $\begin{array}{c}41 \\
(41 \%)\end{array}$ & $\begin{array}{l}22 \\
(44 \%)\end{array}$ & $\begin{array}{l}17 \\
(34 \%)\end{array}$ & $\begin{array}{c}12 \\
(24 \%)\end{array}$ & $\begin{array}{c}151 \\
(35.5 \%)\end{array}$ \\
\hline
\end{tabular}

Table 6:

Antenatal investigations performed at PHC's in Jos, Nigeria

\begin{tabular}{|c|c|c|c|c|c|c|c|}
\hline Investigation & Stadium & Bukuru & Nasarawa & T. Wada & $\begin{array}{l}\text { Angwan } \\
\text { Rogo }\end{array}$ & $\begin{array}{l}\text { Abba } \\
\text { Nashehu }\end{array}$ & Total \\
\hline Haemoglobin & $\begin{array}{c}58 \\
(77.3 \%)\end{array}$ & $\begin{array}{c}86 \\
(86 \%)\end{array}$ & $\begin{array}{c}64 \\
(64 \%)\end{array}$ & $\begin{array}{c}2 \\
(4 \%)\end{array}$ & $\begin{array}{c}23 \\
(46 \%)\end{array}$ & $\begin{array}{c}42 \\
(84 \%)\end{array}$ & $\begin{array}{c}275 \\
(64.7 \%)\end{array}$ \\
\hline Blood group & $\begin{array}{c}53 \\
(70.4 \%)\end{array}$ & - & $\begin{array}{c}99 \\
(99 \%)\end{array}$ & $\begin{array}{c}50 \\
(100 \%)\end{array}$ & $\begin{array}{c}45 \\
(90 \%)\end{array}$ & - & $\begin{array}{c}247 \\
(58.1 \%)\end{array}$ \\
\hline VDRL & - & - & - & - & - & - & - \\
\hline $\begin{array}{l}\text { Sickling/ } \\
\text { Genotype }\end{array}$ & - & - & - & - & - & - & - \\
\hline Urinalysis & $\begin{array}{c}56 \\
(74.5 \%)\end{array}$ & $\begin{array}{c}86 \\
(86 \%)\end{array}$ & $\begin{array}{c}63 \\
(63 \%)\end{array}$ & $\begin{array}{c}41 \\
(82 \%)\end{array}$ & $\begin{array}{c}42 \\
(84 \%)\end{array}$ & $\begin{array}{c}42 \\
(84 \%)\end{array}$ & $\begin{array}{c}330 \\
(77.6 \%)\end{array}$ \\
\hline No test done & $\begin{array}{c}14 \\
(18.6 \%)\end{array}$ & $\begin{array}{c}14 \\
(14 \%)\end{array}$ & - & - & $\begin{array}{c}4 \\
(8 \%)\end{array}$ & $\begin{array}{c}8 \\
(16 \%)\end{array}$ & $\begin{array}{c}40 \\
(9.4 \%)\end{array}$ \\
\hline
\end{tabular}


Audit of Antenatal Services in Primary Care

Table 7:

Routine Antenatal drugs administered at PHCs in Jos, Nigeria

\begin{tabular}{|c|c|c|c|c|c|c|c|}
\hline Parity & Stadium & Bukuru & Nasarawa & $\mathrm{T} /$ Wada & $\begin{array}{l}\text { Angwan } \\
\text { Rogo }\end{array}$ & $\begin{array}{l}\text { Abba } \\
\text { Nashehu }\end{array}$ & Total \\
\hline $\begin{array}{l}\text { Fersolate/ } \\
\text { Folic acid }\end{array}$ & $\begin{array}{c}75 \\
(100 \%)\end{array}$ & $\begin{array}{c}100 \\
(100 \%)\end{array}$ & $\begin{array}{c}99 \\
(99 \%)\end{array}$ & $\begin{array}{c}50 \\
(100 \%)\end{array}$ & $\begin{array}{c}45 \\
(90 \%)\end{array}$ & $\begin{array}{c}44 \\
(88 \%)\end{array}$ & $\begin{array}{c}413 \\
(97.2 \%)\end{array}$ \\
\hline Anti malarial & - & - & - & - & - & - & - \\
\hline None & - & - & $\begin{array}{c}1 \\
(1 \%)\end{array}$ & - & $\begin{array}{c}5 \\
(10 \%)\end{array}$ & $\begin{array}{c}6 \\
(12 \%)\end{array}$ & $\begin{array}{c}12 \\
(2.8 \%)\end{array}$ \\
\hline
\end{tabular}

in the study population had an ultrasound scan done. It is likely that a number of the women referred with intrauterine fetal deaths from PHC's to the teaching hospital are the result of mismanaged prolonged pregnancies.

Blood pressure measurement was done at booking and at subsequent visits in only $132(31 \%)$ cases, indicating that over two-thirds of pregnant women receive antenatal care in the PHCs without blood pressure surveillance. This may account for the high number of eclamptics that are referred to the teaching hospital from these facilities. Eclampsia was reported as the leading cause of maternal mortality in Jos. ${ }^{2}$ It was interesting to note that despite the evidence that weight measurement was of little value in optimizing pregnancy outcome, this was consistently done at each visit in most of the PHC's. The high prevalence of malaria, sickle cell disease and the increasing trend of syphilis in this environment not withstanding ${ }^{4}$, screening tests such as sickling test (or genotype) and VDRL test were not routinely performed in the health facilities. None of the patients received malaria prophylaxis in spite of the evidence that exists of its value ${ }^{12}$. However, iron and folic acid supplementation was consistently administered to the women in all the PHC's.

These findings showed that antenatal services provided in the PHC's in the area studied fall short of prescribed standards and constitute a missed opportunity to impact on the poor materenal and perinatal health statistics in the State.

\section{References}

1. Carroli G, Rooney C, Villar J. Paediatric and Perinatal Epidemiology. Blackwell Science (Ed.) 2001, 15 (suppl. 1), 1-42.

2. Ujah 1, Uguru VE, Aisien AO, Sagay AS and Otubu JAM. How safe is motherhood in Nigeria? The trend of maternal mortality in a tertiary health institution. East Afr MedJ, 1999; Aug. 76(8): 434 437.

3. Aboyeji AP. Trends in maternal mortality in llorin, Nigeria. Trop $J$ Obstet Gynaecol, 1998; 15:15-20

4. National Population Commission [Nigeria] and ORC Macro.2004. Nigeria Demographic and Health Survey 2003: Key findings. Calverton, Maryland, USA: National Population Commission and ORC Macro.

5. Kuti O, Dare FO, Ogunniyi SO. The role of referring centers in the tragedy of unbooked patients. Trop J Obstet Gynaecol, 2001; 18: 24-26

6. Gharoro EP, Igbafe AA. Grand multiparity: Emerging Trend in a Tropical Community. Trop JObstet Gynaecol, 2001; 18:27-30.
In the light of this, we make the following recommendations that:

1. A periodic exchange of staff between primary, secondary and tertiary health institutions should be encouraged as a way of improving the knowledge base and skills of healthcare providers in these facilities.

2. Healthcare workers in PHC's should be encouraged to attend periodic update courses.

3. Regular internal and periodic external audit of the clinical activities at PHC's should be considered.

4. Posters of high-risk obstetric factors requiring referral should be placed in strategic areas in the consulting rooms at PHC's to serve as reminders for the healthcare workers.

5. Basic infrastructure in PHCs should be provided and maintained.

6. Each local government area should consider appointing a supervising consultant obstetrician to maintain the standard of services in its PHCs.

\section{Conclusion}

The standard of antenatal care at the PHC's in Jos falls short of the required level and represents a missed opportunity to impact on the poor maternal and perinatal health statistics in the area. It is unlikely that these deficiencies are confined to our local centres only and should prompt a national review of the operations of PHCs across Nigeria.

7. Hughes PF, Morrison J. Grandmultiparity- not to be feared? An analysis of grandmultiparous women receiving modern antenatal care. Int J Gynaecol Obstet. 1994; 44:211-217.

8. Abotalib Z, Adelusi B, al Mestrar A, al Nuaim A, Chowdhury N, Kangave D. Obstetric outcome in the unbooked mother. EAfr Med J. 1998; Feb. 75(2): 102-106.

9. Neilson JP. Ultrasound for fetal assessment in early pregnancy (Cochrane review), In: The Cochrane library, issue 4, 2003.

10. Kramer MS, McLean FH, Boyd ME, Usher RH. The validity of gestational age estimation by menstrual dating in term, preterm, and post-term gestations. $J A M A 1988 ; 260: 3306-3308$.

11. Crowley $P$. Interventions for preventing or improving outcome of delivery at or beyond term (Cochrane review) In: The Cochrane library, issue 4, 2003.

12. Garner P, Gulmerzoglu A: Drugs for preventing malaria-related illness in pregnant women and death in the newborn (Cochrane Review), In: The Cochrane library, Issue 42003. 